Article

\title{
Silver, Gold, and Iron Oxide Nanoparticles Alter miRNA Expression but Do Not Affect DNA Methylation in HepG2 Cells
}

\author{
Kamil Brzóska ${ }^{1, *(D)}$, Iwona Grądzka ${ }^{1}$ and Marcin Kruszewski ${ }^{1,2,3}$ \\ 1 Institute of Nuclear Chemistry and Technology, Centre for Radiobiology and Biological Dosimetry, \\ Dorodna 16, 03-195 Warsaw, Poland; i.gradzka@ichtj.waw.pl (I.G.); m.kruszewski@ichtj.waw.pl (M.K.) \\ 2 University of Information Technology and Management, Faculty of Medicine, Department of Medical \\ Biology and Translational Research, Sucharskiego 2, 35-225 Rzeszów, Poland \\ 3 Institute of Rural Health, Department of Molecular Biology and Translational Research, Jaczewskiego 2, \\ 20-090 Lublin, Poland \\ * Correspondence: kamil.brzoska@gmail.com; Tel.: +48-22-504-1226
}

Received: 20 February 2019; Accepted: 26 March 2019; Published: 29 March 2019

\begin{abstract}
The increasing use of nanoparticles (NPs) in various applications entails the need for reliable assessment of their potential toxicity for humans. Originally, studies concerning the toxicity of NPs focused on cytotoxic and genotoxic effects, but more recently, attention has been paid to epigenetic changes induced by nanoparticles. In the present research, we analysed the DNA methylation status of genes related to inflammation and apoptosis as well as the expression of miRNAs related to these processes in response to silver (AgNPs), gold (AuNPs), and superparamagnetic iron oxide nanoparticles (SPIONs) at low cytotoxic doses in HepG2 cells. There were no significant differences between treated and control cells in the DNA methylation status. We identified nine miRNAs, the expression of which was significantly altered by treatment with nanoparticles. The highest number of changes was induced by AgNPs (six miRNAs), followed by AuNPs (four miRNAs) and SPIONs (two miRNAs). Among others, AgNPs suppressed miR-34a expression, which is of particular interest since it may be responsible for the previously observed AgNPs-mediated HepG2 cells sensitisation to tumour necrosis factor (TNF). Most of the miRNAs affected by NP treatment in the present study have been previously shown to inhibit cell proliferation and tumourigenesis. However, based on the observed changes in miRNA expression we cannot draw definite conclusions regarding the pro- or anti-tumour nature of the NPs under study. Further research is needed to fully elucidate the relation between observed changes in miRNA expression and the effect of NPs observed at the cellular level. The results of the present study support the idea of including epigenetic testing during the toxicological assessment of the biological interaction of nanomaterials.
\end{abstract}

Keywords: silver nanoparticles; gold nanoparticles; superparamagnetic iron oxide nanoparticles; miRNA expression; DNA methylation; epigenetics

\section{Introduction}

The intensive development of nanotechnology brings great impacts on industry, medicine and many other aspects of society. An increasing use of nanoparticles (NPs) in various applications entails the need for reliable assessment of their potential toxicity for humans. Initially, studies concerning the toxicity of NPs focused on cytotoxic and genotoxic effects [1]. More recently, attention has been paid to epigenetic changes induced by NPs and epigenetic mechanisms underlying observed cytotoxic effects [2,3]. Epigenetics constitute an important link between genotype and phenotype, and plays a critical role in the regulation of numerous cellular processes, such as DNA replication 
and gene expression. Epigenetic regulatory mechanisms include, among others, DNA methylation, histone modification, chromatin remodelling, and expression of non-coding RNAs, including miRNAs. Epigenetic modifications can be very stable and passed on to multiple generations, however, it is becoming increasingly recognized that they can also change dynamically in response to environmental stressors and that altered epigenetic mechanisms can play an essential role in the development and progression of cancer and other diseases [4,5].

It has been shown that several types of nanoparticles induce changes in miRNA expression [6-14], DNA methylation [15-26], as well as histone modifications such as acetylation [20,27], phosphorylation [28,29] and methylation [30]. Three of the most prevalent nanomaterials used in medicine and industry are silver (AgNPs), gold (AuNPs), and superparamagnetic iron oxide nanoparticles (SPIONs). Both AgNPs and AuNPs have been shown to alter miRNA expression and induce DNA methylation $[6,7,11,12,17,20,21]$. Moreover, it has been shown that both types of nanoparticles alter histone $\mathrm{H} 3$ phosphorylation [28,29,31,32], while AgNPs also alter histone H3 methylation [30] and decrease its acetylation [20]. On the other hand, literature on the epigenetic effects of SPIONs is very limited. It has been reported that $\mathrm{Fe}_{2} \mathrm{O}_{3}$ SPIONs affect miRNA expression in $\mathrm{NIH} / 3 \mathrm{~T} 3$ cells [9] and DNA methylation in MCF-7 cells [33]. Epigenetic effects of $\mathrm{Fe}_{3} \mathrm{O}_{4}$ SPIONs have not been studied so far.

In our previous studies, we have extensively analysed the cytotoxicity of AgNPs in cellular and animal models. Using HepG2 and A549 cell lines as an experimental system, we have shown that cellular response to AgNPs is related to the basal activity of cellular signalling pathways [34] and that HepG2 cells can adapt to AgNPs-induced stress [35]. Recently, we have shown that AgNPs, and to a lesser extent AuNPs and SPIONs, can modify the cellular response to external stimuli, such as tumour necrosis factor [36]. Interestingly, SPIONs showed no toxicity in HepG2 cells and were even able to induce cell proliferation in a clonogenic assay [36].

As we and others have previously observed, cellular response to NPs usually consists of changes in the expression of genes related to inflammation and apoptosis [34-38]. To further investigate the molecular mechanism of action of NPs on HepG2 cells, in the present research we analysed the DNA methylation status of genes related to inflammation and apoptosis, as well as the expression of miRNAs related to these processes in response to AgNPs, AuNPs and SPIONs at low cytotoxic doses.

\section{Materials and Methods}

\subsection{Nanoparticle Preparation}

AgNPs of nominal size $20 \mathrm{~nm}$ were purchased from Plasmachem $\mathrm{GmbH}$, Berlin, Germany. AgNPs stock solution was prepared as previously described [39]. In brief, AgNPs ( $2 \mathrm{mg}$ ) were suspended in $800 \mu \mathrm{L}$ of distilled water and sonicated in an ice water bath with a dose of $4.2 \mathrm{~kJ} / \mathrm{cm}^{3}$. One hundred microliters of $15 \%$ bovine serum albumin and $100 \mu \mathrm{L}$ of a $10 \times$ concentrated phosphate-buffered saline (PBS) were added immediately after sonication. Detailed characteristics of the AgNPs in different culture media, including hydrodynamic size, zeta potential, aggregation rate and stability in cell culture media can be found in our previous papers $[36,39,40]$.

Sodium-citrate-coated AuNPs and PVP-coated magnetite $\left(\mathrm{Fe}_{3} \mathrm{O}_{4}\right)$ nanoparticles of $20 \mathrm{~nm}$ nominal size were purchased from NanoComposix, San Diego, CA, USA. According to the manufacturer's data, their hydrodynamic diameters were 24 and $40 \mathrm{~nm}$ and zeta potentials were -43.6 and $-49.7 \mathrm{mV}$, respectively. AuNPs were diluted in the cell culture medium and used in the experiments without additional processing. SPIONs stock solution $(20 \mathrm{mg} / \mathrm{mL})$ was diluted in sterile deionised water to $1 \mathrm{mg} / \mathrm{mL}$ and sonicated for $10 \mathrm{~min}$ in an ice water bath with a dose of $4.2 \mathrm{~kJ} / \mathrm{cm}^{3}$. The stability of AuNPs and SPIONs in the cell culture medium can be found in our previous paper [36]. 


\subsection{Cell Culture}

Human hepatic cell line HepG2 was purchased from the American Type Culture Collection (ATCC, Manassas, VA, USA), and cells were cultured in EMEM medium (ATCC) supplemented with $10 \%$ foetal calf serum (Gibco, Thermo Fisher Scientific, Waltham, MA, USA). The cells were incubated in $5 \% \mathrm{CO}_{2}$ atmosphere at $37^{\circ} \mathrm{C}$. Asynchronous cell cultures in the exponential phase of growth were used in all experiments.

\subsection{Neutral Red Assay}

The neutral red (NR) assay was performed as described previously [41]. Briefly, HepG2 cells were seeded in 96-well microplates (TPP, Trasadingen, Switzerland) at a density of $1.5 \times 10^{4}$ cells $/$ well in $200 \mu \mathrm{L}$ of culture medium. Twenty-four hours after seeding, cells were treated with nanoparticles $(10 \mu \mathrm{g} / \mathrm{mL}$ AgNPs, $10 \mu \mathrm{g} / \mathrm{mL}$ AuNPs, $5 \mu \mathrm{g} / \mathrm{mL}$ SPIONs). After $24 \mathrm{~h}$, the cell culture medium was removed, the cells were washed with $150 \mu \mathrm{L}$ PBS and incubated for $3 \mathrm{~h}$ at $37^{\circ} \mathrm{C}$ with $100 \mu \mathrm{L}$ of the neutral red solution at a final concentration of $40 \mu \mathrm{g} / \mathrm{mL}$. Next, the NR solution was aspirated, cells were washed with $150 \mu \mathrm{L}$ of PBS, and $150 \mu \mathrm{L}$ of an acetic acid-ethanol solution (49\% water, $50 \%$ ethanol and $1 \%$ acetic acid) was added to each well. After 15 min of gentle shaking, the optical density was read at $540 \mathrm{~nm}$ in the plate reader spectrophotometer Infinite M200 (Tecan, Männedorf, Switzerland). Four independent experiments in three replicate wells were conducted per experimental point.

\subsection{Methylation Analysis}

For DNA methylation analysis, cells were seeded onto 60-mm cell culture dishes $24 \mathrm{~h}$ before treatment. Subsequently, nanoparticle stock suspension (or carrier mix for control plate) was added directly to the cell culture to obtain the final concentration $(10 \mu \mathrm{g} / \mathrm{mL}$ AgNPs, $10 \mu \mathrm{g} / \mathrm{mL}$ AuNPs, $5 \mu \mathrm{g} / \mathrm{mL}$ SPIONs). After incubation for $24 \mathrm{~h}$, the cells were washed with PBS, trypsinised and harvested for DNA isolation. Genomic DNA was isolated from the cell pellets using the DNeasy Blood and Tissue kit (Qiagen, Hilden, Germany) using a protocol supplied by the manufacturer. Promoter methylation of genes related to inflammatory response and apoptosis was analysed using EpiTect Methyl II PCR Array Human Inflammatory Response \& Autoimmunity Signature Panel and EpiTect Methyl II PCR Array Human Apoptosis Signature Panel (Qiagen, Hilden, Germany). The method is based on detecting remaining DNA input after cleavage with methylation-sensitive and/or methylation-dependent restriction enzymes. The DNA was digested using EpiTect II DNA Methylation Enzyme Kit (Qiagen, Hilden, Germany) following the manufacturer's protocol. After digestion, quantification of remaining DNA in each enzyme reaction was carried out by real-time PCR using RT ${ }^{2}$ SYBR Green ROX qPCR Mastermix (Qiagen, Hilden, Germany) in the 7500 Real-Time PCR system (Applied Biosystems, Thermo Fisher Scientific, Waltham, MA, USA). The thermal cycler was programmed according to the manufacturer's instructions, using the following PCR cycling protocol: 1 cycle of $95{ }^{\circ} \mathrm{C}$ for $10 \mathrm{~min}, 3$ cycles of $99^{\circ} \mathrm{C}$ for $30 \mathrm{~s}, 72{ }^{\circ} \mathrm{C}$ for $1 \mathrm{~min} ; 40$ cycles of $97^{\circ} \mathrm{C}$ for $15 \mathrm{~s}$, $72{ }^{\circ} \mathrm{C}$ for $1 \mathrm{~min}$. The assay provided gene methylation status as a percentage of the methylated and unmethylated fractions of input DNA. Each array included specific control assays for monitoring the cutting efficiencies of methylation-sensitive and methylation-dependent enzymes and ensuring reliable and reproducible results. Data were assessed using the Excel template released by Qiagen, Hilden, Germany Version 2.0, 02/03/2012.

\subsection{Analysis of miRNA Expression by Real-Time PCR}

For miRNA expression experiments, cells were seeded onto 60-mm cell culture dishes $24 \mathrm{~h}$ before treatment. Subsequently, nanoparticle stock suspension (or carrier mix for control plate) was added directly to the cell culture to obtain the final concentration $(10 \mu \mathrm{g} / \mathrm{mL}$ AgNPs, $10 \mu \mathrm{g} / \mathrm{mL}$ AuNPs, $5 \mu \mathrm{g} / \mathrm{mL}$ SPIONs). After incubation for $6 \mathrm{~h}$, the cells were washed with PBS, trypsinised and harvested for RNA isolation. Total RNA including miRNA was extracted from the cell pellets using a miRNeasy 
Mini Kit (Qiagen, Hilden, Germany) according to the manufacturer's protocol. The RNA concentration was measured using a Quantus Fluorometer (Promega, Madison, WI, USA) and the QuantiFluor RNA System (Promega, Madison, WI, USA). Reverse transcription reactions were performed using a miScript II RT Kit (Qiagen, Hilden, Germany). The reaction mix contained 250 ng template RNA, $1 \times$ miScript HiSpec Buffer (to specifically convert mature miRNAs into cDNA), $1 \times$ miScript Nucleics Mix, RNase-free water and miScript Reverse Transcriptase Mix in a final volume of $20 \mu \mathrm{L}$. Reverse transcription mix was incubated for $60 \mathrm{~min}$ at $37^{\circ} \mathrm{C}$, followed by $5 \mathrm{~min}$ at $95^{\circ} \mathrm{C}$ to inactivate the reverse transcriptase. Subsequently, samples were diluted with $200 \mu \mathrm{L}$ RNase-free water and submitted to real-time PCR analysis using miScript miRNA PCR Array Human Apoptosis (Qiagen, Hilden, Germany), miScript miRNA PCR Array Human Inflammatory Response \& Autoimmunity (Qiagen, Hilden, Germany) and miScript SYBR Green PCR Kit (Qiagen, Hilden, Germany). PCR amplification was performed using a 7500 Real-Time PCR System (Applied Biosystems, Thermo Fisher Scientific, Waltham, MA, USA) with an initial 15 min step at $95^{\circ} \mathrm{C}$ followed by 40 cycles of $94^{\circ} \mathrm{C}$ for $15 \mathrm{~s}, 55^{\circ} \mathrm{C}$ for $30 \mathrm{~s}$ and $70{ }^{\circ} \mathrm{C}$ for $34 \mathrm{~s}$. Relative miRNA expression was calculated using the $\Delta \Delta \mathrm{Ct}$ method with SNORD61, SNORD68, SNORD95 and SNORD96A as endogenous controls. Calculations were done using Relative Quantification Software version 3.2.1-PRC-build1 (Thermo Fisher Cloud, Thermo Fisher Scientific, Waltham, MA, USA). Statistical differences were examined by Student's $t$-test with $p<0.05$ considered to be statistically significant.

\subsection{Statistical Evaluation}

Except for miRNA expression, statistical analysis of the obtained data was performed using Statistica 7.1 software (StatSoft, Tulsa, OK, USA). The data were expressed as the mean \pm standard deviation from at least three independent experiments. Statistical significance was evaluated using Student's $t$-test. Differences were considered statistically significant when the $p$-value was $<0.05$.

\section{Results}

\subsection{Nanoparticles in Selected Concentrations Have a Marginal Effect on Cell Viability}

Based on our previous research, for the present study we chose doses of nanoparticles that expressed minimal toxicity in HepG2 cells. The impact of AgNPs, AuNPs and SPIONs on cell viability was confirmed in the neutral red assay. It revealed that selected concentrations of AuNPs and SPIONs had no significant impact on the viability of HepG2 cells after $24 \mathrm{~h}$ treatment. Still, a small decrease in HepG2 viability after AgNPs treatment was observed (Figure 1). Internalization of the NPs under study into HepG2 cells was proven using flow cytometry as reported in our previous paper [36]. 


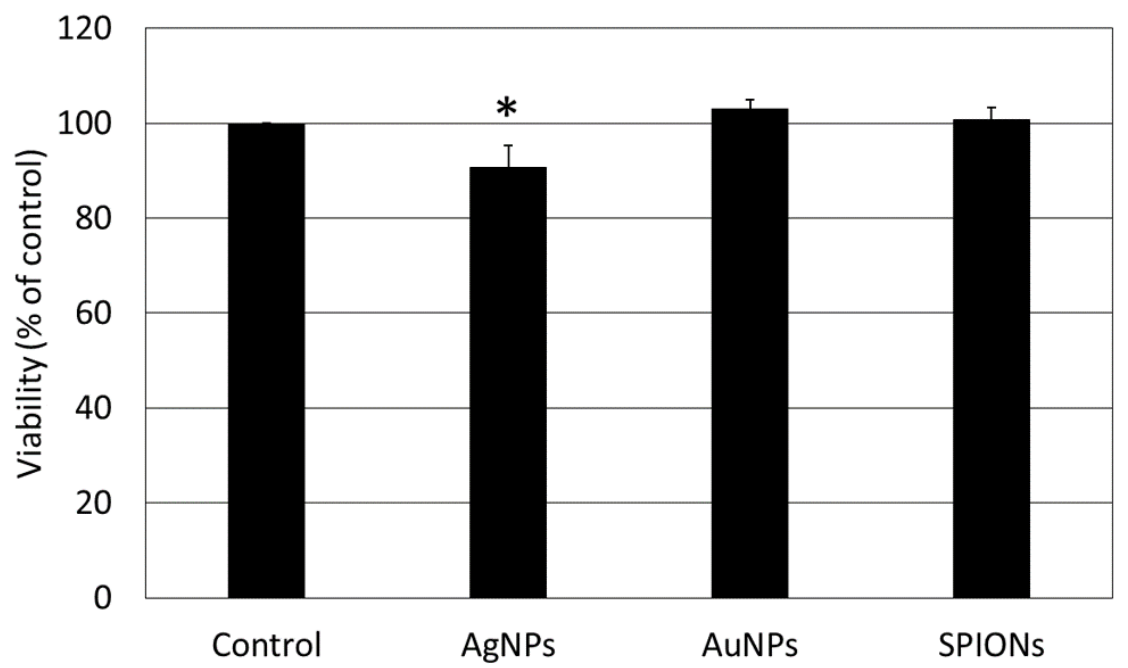

Figure 1. The viability of HepG2 cells measured by the neutral red assay. Cells were treated with silver nanoparticles (AgNPs; $10 \mu \mathrm{g} / \mathrm{mL}$ ), gold nanoparticles (AuNPs; $10 \mu \mathrm{g} / \mathrm{mL}$ ) and superparamagnetic iron oxide nanoparticles (SPIONs; $5 \mu \mathrm{g} / \mathrm{mL}$ ) for $24 \mathrm{~h}$. Data are presented as the mean \pm standard deviation from four independent experiments. Asterisk denotes a statistically significant difference versus the control group.

\subsection{Nanoparticles Do Not Affect the Methylation Status of Genes Related to Apoptosis and Inflammation}

HepG2 cells were treated with NPs for $24 \mathrm{~h}$, and the methylation status of the promoter region of 44 genes related to apoptosis and inflammatory response was compared between treated and control cells using EpiTect Methyl II PCR Arrays. There were no significant differences between treated and control cells in the methylation status of genes under study for any type of nanoparticles. Thirty-one genes were unmethylated, six were methylated, and seven were partially methylated. The detailed results are presented in Table 1.

Table 1. Methylation analysis of the promoter region of selected genes related to inflammatory response and apoptosis. HepG2 cells were treated with AgNPs $(10 \mu \mathrm{g} / \mathrm{mL})$, AuNPs $(10 \mu \mathrm{g} / \mathrm{mL})$ and SPIONs $(5 \mu \mathrm{g} / \mathrm{mL})$ for $24 \mathrm{~h}$. Data are presented as the mean from three independent experiments. Differences were not statistically significant.

\begin{tabular}{ccccc}
\hline \multirow{2}{*}{ Gene Symbol } & \multicolumn{5}{c}{$\%$ Methylated } \\
\cline { 2 - 5 } & Control & AgNPs & AuNPs & SPIONs \\
\hline APAF1 & 0 & 0 & 0 & 0 \\
\hline$A T F 2$ & 0 & 0 & 0 & 0 \\
\hline$B A D$ & 0 & 0 & 0 & 0 \\
\hline$B A X$ & 0 & 0 & 0 & 0 \\
\hline$B C L 2 L 11$ & 100 & 100 & 100 & 100 \\
\hline$B C L A F 1$ & 0 & 0 & 0 & 0 \\
\hline$B I D$ & 0 & 0 & 0 & 0 \\
\hline$B I K$ & 63 & 64 & 58 & 62 \\
\hline BIRC2 & 0 & 0 & 0 & 0 \\
\hline$B N I P 3 L$ & 0 & 0 & 0 & 0 \\
\hline CASP3 & 0 & 0 & 0 & 0 \\
\hline CASP9 & 2 & 2 & 3 & 2 \\
\hline CCL25 & 71 & 72 & 68 & 70 \\
\hline
\end{tabular}


Table 1. Cont.

\begin{tabular}{|c|c|c|c|c|}
\hline \multirow{2}{*}{ Gene Symbol } & \multicolumn{4}{|c|}{$\%$ Methylated } \\
\hline & Control & AgNPs & AuNPs & SPIONs \\
\hline CIDEB & 100 & 100 & 100 & 100 \\
\hline$C R A D D$ & 0 & 0 & 0 & 0 \\
\hline CXCL14 & 75 & 71 & 71 & 72 \\
\hline CXCL3 & 66 & 63 & 66 & 65 \\
\hline CXCL5 & 76 & 72 & 75 & 75 \\
\hline CXCL6 & 99 & 99 & 99 & 99 \\
\hline$D A P K 1$ & 0 & 0 & 0 & 0 \\
\hline DFFA & 0 & 0 & 0 & 0 \\
\hline FADD & 0 & 0 & 0 & 0 \\
\hline$F A D D$ & 0 & 0 & 0 & 0 \\
\hline GADD $45 A$ & 0 & 0 & 0 & 0 \\
\hline GATA3 & 0 & 0 & 0 & 0 \\
\hline$H R K$ & 0 & 0 & 0 & 0 \\
\hline IL10RA & 78 & 78 & 72 & 75 \\
\hline IL12A & 0 & 0 & 0 & 0 \\
\hline IL12B & 0 & 0 & 0 & 1 \\
\hline IL13 & 96 & 99 & 98 & 93 \\
\hline IL13RA1 & 1 & 1 & 1 & 6 \\
\hline IL15 & 0 & 0 & 0 & 0 \\
\hline IL17C & 100 & 100 & 100 & 100 \\
\hline IL17RA & 66 & 63 & 66 & 64 \\
\hline$I L 4 R$ & 0 & 0 & 0 & 1 \\
\hline IL6R & 0 & 0 & 0 & 0 \\
\hline IL6ST & 0 & 0 & 0 & 0 \\
\hline IL7 & 0 & 0 & 0 & 0 \\
\hline INHA & 0 & 0 & 0 & 0 \\
\hline$L T B R$ & 0 & 0 & 0 & 0 \\
\hline TNFRSF21 & 0 & 0 & 0 & 0 \\
\hline TNFRSF25 & 100 & 100 & 100 & 100 \\
\hline ТP53 & 0 & 0 & 0 & 0 \\
\hline TYK2 & 0 & 0 & 0 & 1 \\
\hline
\end{tabular}

\subsection{Nanoparticles Induce Changes in miRNA Expression}

In order to check if nanoparticles affect the expression of 131 miRNAs related to inflammatory response and apoptosis, we analysed their expression in HepG2 cells treated with nanoparticles using miScript miRNA PCR Array Human Apoptosis and miScript miRNA PCR Array Human Inflammatory Response \& Autoimmunity. We identified nine miRNAs, the expression of which was significantly changed by treatment with nanoparticles. In five cases expression was decreased (Figure 2) and in four cases expression was increased (Figure 3) after treatment with NPs. As could be expected, the different types of nanoparticles did not act in the same way. The highest number of changes was induced by AgNPs (six miRNAs), followed by AuNPs (four miRNAs) and SPIONs (two miRNAs). Interestingly, 
the overlap between different types of NPs was quite small. Only three miRNAs were induced by more than one type of NPs, that is, miR-499a (expression decreased by AgNPs and AuNPs), miR-491-5p (expression decreased by AuNPs and SPIONs) and miR-1-3p (expression increased by AgNPs and SPIONs). The detailed results of miRNA expression analysis can be found in Supplementary Table S1.
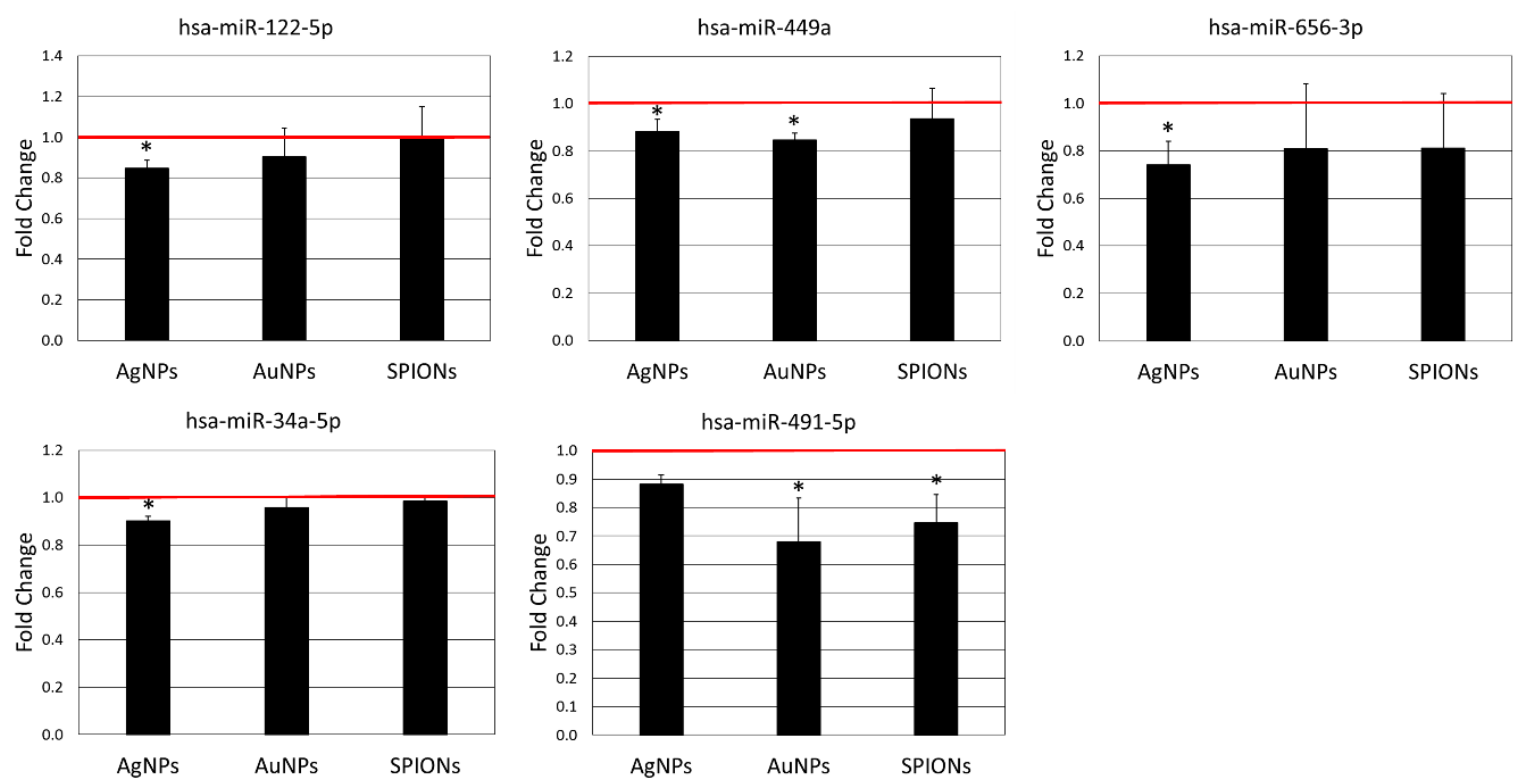

Figure 2. Expression of miRNAs down-regulated by AgNPs $(10 \mu \mathrm{g} / \mathrm{mL})$, AuNPs $(10 \mu \mathrm{g} / \mathrm{mL})$ or SPIONs $(5 \mu \mathrm{g} / \mathrm{mL})$ treatment for $6 \mathrm{~h}$. Data are expressed as the mean \pm standard deviation from three independent experiments. The red line shows the expression level in the control group. Asterisks denote a statistically significant difference versus the control group.
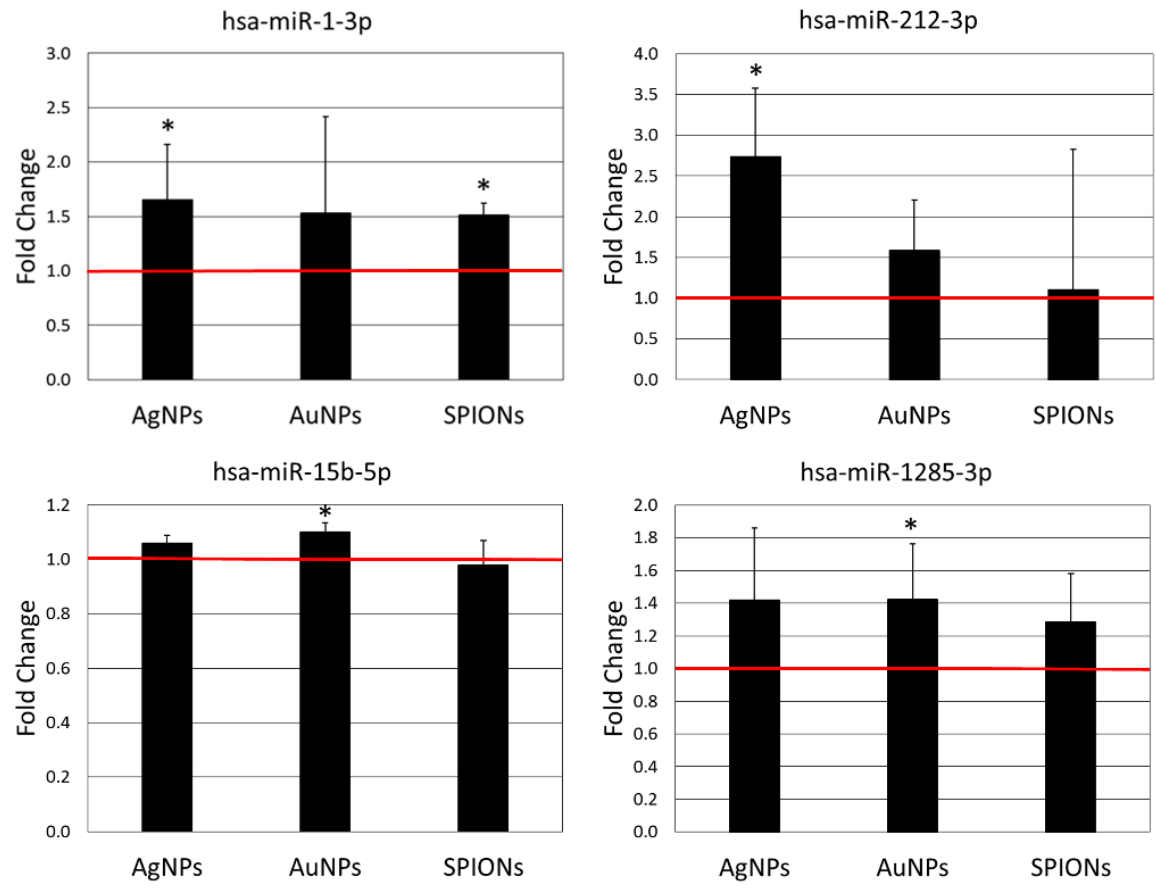

Figure 3. Expression of miRNAs up-regulated by AgNPs $(10 \mu \mathrm{g} / \mathrm{mL})$, AuNPs $(10 \mu \mathrm{g} / \mathrm{mL})$ or SPIONs $(5 \mu \mathrm{g} / \mathrm{mL})$ treatment for $6 \mathrm{~h}$. Data are expressed as the mean \pm standard deviation from three independent experiments. The red line shows the expression level in the control group. Asterisks denote a statistically significant difference versus the control group. 


\section{Discussion}

DNA methylation is a covalent chemical modification of cytosines at the $\mathrm{C} 5$ position with a methyl group and occurs at $\mathrm{CpG}$ dinucleotides clustered into $\mathrm{CpG}$ islands. It affects DNA accessibility to the cellular transcriptional machinery and typically inhibits gene expression [42]. In our experimental setup, we did not observe any changes in the promoter methylation of genes related to inflammation and apoptosis in HepG2 cells after treatment with AgNPs, AuNPs and SPIONs (Table 1). To our knowledge, this is the first report on DNA methylation in HepG2 cells following nanoparticles exposure and the first report on the analysis of DNA methylation after treatment with magnetite $\left(\mathrm{Fe}_{3} \mathrm{O}_{4}\right)$ SPIONs. It has been previously reported that AgNPs induce global DNA methylation in A549 [20] and HT22 cells [21], and a gene-specific methylation in BEAS-2B cells [43] and zebrafish embryos [44]. The only report concerning the impact of AuNPs on DNA methylation shows the induction of methylation of several genes in mouse lungs in vivo [17]. Similarly, the only report regarding SPIONs' impact on DNA methylation shows that maghemite $\left(\gamma-\mathrm{Fe}_{2} \mathrm{O}_{3}\right)$ nanoparticles did not affect global DNA methylation in MCF-7 cells, but affect the methylation of several specific genes [33]. It seems that the impact of nanoparticles on DNA methylation is cell-type-specific and highly dependent on the properties of the nanomaterial. Nevertheless, the present results suggest that gene expression changes observed previously in HepG2 cells after NPs treatment [36] are unlikely to be induced by changes in DNA methylation.

One of the most frequently studied epigenetic mechanisms is miRNA expression. miRNAs are endogenous, short ( 22 nucleotides), non-coding RNAs regulating gene expression at post-transcriptional and translational levels via complementary base-pairing with target mRNA. miRNAs play an essential role in a broad range of cellular processes, including proliferation, differentiation, stress response and apoptosis [45]. High complementarity of miRNA and its mRNA target results in mRNA cleavage through an RNA interference mechanism. In contrast, partial complementarity, which is commonly seen in mammalian cells, results in translational inhibition. Single miRNAs can simultaneously regulate multiple targets or even whole biological networks [46].

The effect of AgNPs on miRNA expression has been tested only in vitro so far, with significant miRNA expression changes observed in human dermal fibroblasts [47], Jurkat cells [11] and neural cells [12]. Similarly, the modulation of miRNA expression by AuNPs has been shown in vitro in human dermal fibroblasts [7] and lung fibroblasts [10]. It has also been reported that administration of $100 \mathrm{~nm}$ AuNPs to pregnant mice alters miRNA expression in foetal lungs and liver. Interestingly, 40 $\mathrm{nm}$ AuNPs did not produce any adverse effects in this experimental system [6]. To our knowledge, the impact of $\mathrm{Fe}_{3} \mathrm{O}_{4}$ SPIONs on miRNA expression has not been studied so far. Li et al. reported that in NIH/3T3 cells $\mathrm{Fe}_{2} \mathrm{O}_{3}$ SPIONs affected the expression of various miRNAs, including an increased expression of miR-34a [9]. Similarly, Huang et al. reported an increase in miR-34a expression in human dermal fibroblasts in response to AuNPs [7]. In our study, miR-34a was slightly downregulated by AgNPs, but was not affected by AuNPs nor $\mathrm{Fe}_{3} \mathrm{O}_{4}$ SPIONs (Figure 2).

Guennewig et al. have shown that miR-34a targets the tumour necrosis factor (TNF) gene and inhibits LPS-induced TNF expression in macrophages [48]. In our previous study, we observed a synergistic effect of AgNPs and TNF on TNF gene expression in HepG2 cells [36], which may be attributed to the suppression of miR-34a expression by AgNPs observed in this study. On the other hand, Wan et al. showed that miR-34a was induced by oxidative stress in a p53-dependent manner in hepatocellular carcinoma [49]. As oxidative stress induction is regarded as a primary mechanism of AgNPs' action inside a cell [39], increased miR-34a level in the AgNPs-treated cells could be expected. This is in contrast with the decreased miR-34a expression observed in our study. As miR-34a induction in response to oxidative stress is dependent on p53 activation, we can speculate that in our study oxidative stress caused by AgNPs was not sufficient to induce a significant amount of DNA damage to trigger p53 activation.

All of the miRNAs affected by treatment with NPs in the present study, except miR-15b-5p, have previously been shown to inhibit cell proliferation and tumourigenesis via different 
mechanisms [50-57]. miR-15b-5p was previously reported both as facilitating or suppressing tumorigenesis [58,59]. Modulation of miRNA expression by NPs constitutes a possible mechanism by which NPs can promote or inhibit tumour initiation and/or progression. However, based on the observed changes in miRNA expression we cannot draw a definite conclusion regarding the pro- or anti-tumour nature of the NPs under study. The observed pattern of miRNA expression induced by NPs is ambiguous. All NPs under study both induce and inhibit expression of miRNAs with reported tumour-suppressing activity (Figures 2 and 3).

AgNPs, AuNPs and SPIONs are already used or are planned to be used in numerous applications in biology and medicine as anti-microbial agents, radio-sensitizers, drug carriers and contrast agents. The effects of these NPs on miRNA expression observed in the present work as well as previously reported effects on the gene expression and activity of cellular signalling pathways [34-36] do not preclude their usefulness in biological and medical applications. Nevertheless, the observed effects must be taken into consideration during the development of such applications.

Taken together, the results of the present study support the idea of including epigenetic testing during the toxicological assessment of the biological interaction of nanomaterials. For the first time, we have shown that commonly used NPs induce miRNA expression changes in HepG2 cells. We have also shown that the mechanism of action of these NPs on HepG2 cells is not related to the changes in methylation of the promoter region of genes related to inflammation and apoptosis. Further research is needed to fully elucidate the relationship between observed changes in miRNA expression and the effects of NPs observed at the cellular level.

Supplementary Materials: The following are available online at http:/ /www.mdpi.com/1996-1944/12/7/1038/ s1. Table S1: The detailed results of miRNA expression analysis.

Author Contributions: Conceptualization, K.B. and M.K.; methodology, K.B. and I.G.; investigation, K.B. and I.G.; formal analysis, K.B.; writing—original draft preparation, K.B. and M.K.; writing-review \& editing, K.B., I.G. and M.K.; supervision, M.K.; project administration, K.B.; funding acquisition, K.B.

Funding: This work was supported by the grant 2014/13/D/NZ7/00286 from National Science Centre, Poland and statutory funding to Institute of Nuclear Chemistry and Technology.

Conflicts of Interest: The authors declare no conflict of interest.

\section{References}

1. Kruszewski, M.; Brzoska, K.; Brunborg, G.; Asare, N.; Dobrzynska, M.; Dusinska, M.; Fjellsbo, L.M.; Georgantzopoulou, A.; Gromadzka-Ostrowska, J.; Gutleb, A.C.; et al. Toxicity of Silver Nanomaterials in Higher Eukaryotes. Adv. Molec. Toxicol. 2011, 5, 179-218.

2. Sierra, M.I.; Valdes, A.; Fernandez, A.F.; Torrecillas, R.; Fraga, M.F. The effect of exposure to nanoparticles and nanomaterials on the mammalian epigenome. Int. J. Nanomedicine 2016, 11, 6297-6306. [CrossRef]

3. Wong, B.S.E.; Hu, Q.; Baeg, G.H. Epigenetic modulations in nanoparticle-mediated toxicity. Food. Chem. Toxicol. 2017, 109 Pt 1, 746-752. [CrossRef]

4. Feil, R.; Fraga, M.F. Epigenetics and the environment: Emerging patterns and implications. Nat. Rev. Genet. 2012, 13, 97-109. [CrossRef] [PubMed]

5. Koturbash, I.; Beland, F.A.; Pogribny, I.P. Role of epigenetic events in chemical carcinogenesis-A justification for incorporating epigenetic evaluations in cancer risk assessment. Toxicol. Mech. Methods 2011, 21, $289-297$. [CrossRef]

6. Balansky, R.; Longobardi, M.; Ganchev, G.; Iltcheva, M.; Nedyalkov, N.; Atanasov, P.; Toshkova, R.; De Flora, S.; Izzotti, A. Transplacental clastogenic and epigenetic effects of gold nanoparticles in mice. Mutat. Res. 2013, 751-752, 42-48. [CrossRef] [PubMed]

7. Huang, Y.; Lu, X.; Qu, Y.; Yang, Y.; Wu, S. MicroRNA sequencing and molecular mechanisms analysis of the effects of gold nanoparticles on human dermal fibroblasts. Biomaterials 2015, 37, 13-24. [CrossRef] [PubMed]

8. Alinovi, R.; Goldoni, M.; Pinelli, S.; Ravanetti, F.; Galetti, M.; Pelosi, G.; De Palma, G.; Apostoli, P.; Cacchioli, A.; Mutti, A.; et al. Titanium dioxide aggregating nanoparticles induce autophagy and under-expression of microRNA 21 and 30a in A549 cell line: A comparative study with cobalt(II, III) oxide nanoparticles. Toxicol. In Vitro 2017, 42, 76-85. [CrossRef] 
9. Li, S.; Wang, H.; Qi, Y.; Tu, J.; Bai, Y.; Tian, T.; Huang, N.; Wang, Y.; Xiong, F.; Lu, Z.; et al. Assessment of nanomaterial cytotoxicity with SOLiD sequencing-based microRNA expression profiling. Biomaterials 2011, 32, 9021-9030. [CrossRef]

10. Ng, C.T.; Dheen, S.T.; Yip, W.C.; Ong, C.N.; Bay, B.H.; Lanry Yung, L.Y. The induction of epigenetic regulation of PROS1 gene in lung fibroblasts by gold nanoparticles and implications for potential lung injury. Biomaterials 2011, 32, 7609-7615. [CrossRef]

11. Eom, H.J.; Chatterjee, N.; Lee, J.; Choi, J. Integrated mRNA and micro RNA profiling reveals epigenetic mechanism of differential sensitivity of Jurkat T cells to AgNPs and Ag ions. Toxicol. Lett. 2014, 229, 311-318. [CrossRef]

12. Oh, J.H.; Son, M.Y.; Choi, M.S.; Kim, S.; Choi, A.Y.; Lee, H.A.; Kim, K.S.; Kim, J.; Song, C.W.; Yoon, S. Integrative analysis of genes and miRNA alterations in human embryonic stem cells-derived neural cells after exposure to silver nanoparticles. Toxicol. Appl. Pharmacol. 2016, 299, 8-23. [CrossRef]

13. Nagano, T.; Higashisaka, K.; Kunieda, A.; Iwahara, Y.; Tanaka, K.; Nagano, K.; Abe, Y.; Kamada, H.; Tsunoda, S.; Nabeshi, H.; et al. Liver-specific microRNAs as biomarkers of nanomaterial-induced liver damage. Nanotechnology 2013, 24, 405102. [CrossRef] [PubMed]

14. Halappanavar, S.; Jackson, P.; Williams, A.; Jensen, K.A.; Hougaard, K.S.; Vogel, U.; Yauk, C.L.; Wallin, H. Pulmonary response to surface-coated nanotitanium dioxide particles includes induction of acute phase response genes, inflammatory cascades, and changes in microRNAs: A toxicogenomic study. Environ. Mol. Mutagen. 2011, 52, 425-439. [CrossRef]

15. Lu, X.; Miousse, I.R.; Pirela, S.V.; Melnyk, S.; Koturbash, I.; Demokritou, P. Short-term exposure to engineered nanomaterials affects cellular epigenome. Nanotoxicology 2016, 10, 140-150. [CrossRef] [PubMed]

16. Li, J.; Tian, M.; Cui, L.; Dwyer, J.; Fullwood, N.J.; Shen, H.; Martin, F.L. Low-dose carbon-based nanoparticle-induced effects in A549 lung cells determined by biospectroscopy are associated with increases in genomic methylation. Sci. Rep. 2016, 6, 20207. [CrossRef] [PubMed]

17. Tabish, A.M.; Poels, K.; Byun, H.M.; Luyts, K.; Baccarelli, A.A.; Martens, J.; Kerkhofs, S.; Seys, S.; Hoet, P.; Godderis, L. Changes in DNA Methylation in Mouse Lungs after a Single Intra-Tracheal Administration of Nanomaterials. PLoS ONE 2017, 12, e0169886. [CrossRef]

18. Oner, D.; Ghosh, M.; Bove, H.; Moisse, M.; Boeckx, B.; Duca, R.C.; Poels, K.; Luyts, K.; Putzeys, E.; Van Landuydt, K.; et al. Differences in MWCNT- and SWCNT-induced DNA methylation alterations in association with the nuclear deposition. Part. Fibre Toxicol. 2018, 15, 11. [CrossRef]

19. Zou, Y.; Li, Q.; Jiang, L.; Guo, C.; Li, Y.; Yu, Y.; Li, Y.; Duan, J.; Sun, Z. DNA Hypermethylation of CREB3L1 and Bcl-2 Associated with the Mitochondrial-Mediated Apoptosis via PI3K/Akt Pathway in Human BEAS-2B Cells Exposure to Silica Nanoparticles. PLoS ONE 2016, 11, e0158475. [CrossRef]

20. Blanco, J.; Lafuente, D.; Gomez, M.; Garcia, T.; Domingo, J.L.; Sanchez, D.J. Polyvinyl pyrrolidone-coated silver nanoparticles in a human lung cancer cells: Time- and dose-dependent influence over p53 and caspase-3 protein expression and epigenetic effects. Arch. Toxicol. 2017, 91, 651-666. [CrossRef]

21. Mytych, J.; Zebrowski, J.; Lewinska, A.; Wnuk, M. Prolonged Effects of Silver Nanoparticles on p53/p21 Pathway-Mediated Proliferation, DNA Damage Response, and Methylation Parameters in HT22 Hippocampal Neuronal Cells. Mol. Neurobiol. 2017, 54, 1285-1300. [CrossRef]

22. Gong, C.; Tao, G.; Yang, L.; Liu, J.; Liu, Q.; Zhuang, Z. SiO(2) nanoparticles induce global genomic hypomethylation in HaCaT cells. Biochem. Biophys. Res. Commun. 2010, 397, 397-400. [CrossRef] [PubMed]

23. Gong, C.; Tao, G.; Yang, L.; Liu, J.; Liu, Q.; Li, W.; Zhuang, Z. Methylation of PARP-1 promoter involved in the regulation of nano-SiO2-induced decrease of PARP-1 mRNA expression. Toxicol. Lett. 2012, 209, 264-269. [CrossRef]

24. Bai, W.; Chen, Y.; Gao, A. Cross talk between poly(ADP-ribose) polymerase 1 methylation and oxidative stress involved in the toxic effect of anatase titanium dioxide nanoparticles. Int. J. Nanomedicine 2015, 10, 5561-5569.

25. Patil, N.A.; Gade, W.N.; Deobagkar, D.D. Epigenetic modulation upon exposure of lung fibroblasts to TiO2 and $\mathrm{ZnO}$ nanoparticles: Alterations in DNA methylation. Int. J. Nanomedicine 2016, 11, 4509-4519.

26. Lu, X.; Miousse, I.R.; Pirela, S.V.; Moore, J.K.; Melnyk, S.; Koturbash, I.; Demokritou, P. In vivo epigenetic effects induced by engineered nanomaterials: A case study of copper oxide and laser printer-emitted engineered nanoparticles. Nanotoxicology 2016, 10, 629-639. [CrossRef] [PubMed] 
27. Choi, A.O.; Brown, S.E.; Szyf, M.; Maysinger, D. Quantum dot-induced epigenetic and genotoxic changes in human breast cancer cells. J. Mol. Med. 2008, 86, 291-302. [CrossRef] [PubMed]

28. Surapaneni, S.K.; Bashir, S.; Tikoo, K. Gold nanoparticles-induced cytotoxicity in triple negative breast cancer involves different epigenetic alterations depending upon the surface charge. Sci. Rep. 2018, 8, 12295. [CrossRef]

29. Zhao, X.; Toyooka, T.; Ibuki, Y. Silver nanoparticle-induced phosphorylation of histone H3 at serine 10 is due to dynamic changes in actin filaments and the activation of Aurora kinases. Toxicol. Lett. 2017, 276, 39-47. [CrossRef] [PubMed]

30. Qian, Y.; Zhang, J.; Hu, Q.; Xu, M.; Chen, Y.; Hu, G.; Zhao, M.; Liu, S. Silver nanoparticle-induced hemoglobin decrease involves alteration of histone 3 methylation status. Biomaterials 2015, 70, 12-22. [CrossRef]

31. Zhao, X.; Takabayashi, F.; Ibuki, Y. Coexposure to silver nanoparticles and ultraviolet A synergistically enhances the phosphorylation of histone H2AX. J. Photochem. Photobiol. B 2016, 162, 213-222. [CrossRef] [PubMed]

32. Zhao, X.; Ibuki, Y. Evaluating the toxicity of silver nanoparticles by detecting phosphorylation of histone H3 in combination with flow cytometry side-scattered light. Environ. Sci. Technol. 2015, 49, 5003-5012. [CrossRef]

33. Bonadio, R.S.; Arcanjo, A.C.; Lima, E.C.; Vasconcelos, A.T.; Silva, R.C.; Horst, F.H.; Azevedo, R.B.; Pocas-Fonseca, M.J.; Longo, J.P.F. DNA methylation alterations induced by transient exposure of MCF-7 cells to maghemite nanoparticles. Nanomedicine (Lond.) 2017, 12, 2637-2649. [CrossRef]

34. Stepkowski, T.M.; Brzoska, K.; Kruszewski, M. Silver nanoparticles induced changes in the expression of NF-kappaB related genes are cell type specific and related to the basal activity of NF-kappaB. Toxicol. In Vitro 2014, 28, 473-478. [CrossRef] [PubMed]

35. Brzoska, K.; Meczynska-Wielgosz, S.; Stepkowski, T.M.; Kruszewski, M. Adaptation of HepG2 cells to silver nanoparticles-induced stress is based on the pro-proliferative and anti-apoptotic changes in gene expression. Mutagenesis 2015, 30, 431-439. [CrossRef] [PubMed]

36. Brzoska, K.; Gradzka, I.; Kruszewski, M. Impact of silver, gold, and iron oxide nanoparticles on cellular response to tumor necrosis factor. Toxicol. Appl. Pharmacol. 2018, 356, 140-150. [CrossRef] [PubMed]

37. Chezeau, L.; Sebillaud, S.; Safar, R.; Seidel, C.; Dembele, D.; Lorcin, M.; Langlais, C.; Grossmann, S.; Nunge, H.; Michaux, S.; et al. Short- and long-term gene expression profiles induced by inhaled TiO2 nanostructured aerosol in rat lung. Toxicol. Appl. Pharmacol. 2018, 356, 54-64. [CrossRef]

38. Ng, C.T.; Yip, G.W.C.; Chen, E.S.; Poh, W.Y.R.; Bay, B.H.; Yung, L.Y.L. Gold nanoparticles induce serum amyloid A 1-Toll-like receptor 2 mediated NF-kB signaling in lung cells in vitro. Chem. Biol. Interact. 2018, 289, 81-89. [CrossRef] [PubMed]

39. Kruszewski, M.; Gradzka, I.; Bartlomiejczyk, T.; Chwastowska, J.; Sommer, S.; Grzelak, A.; Zuberek, M.; Lankoff, A.; Dusinska, M.; Wojewodzka, M. Oxidative DNA damage corresponds to the long term survival of human cells treated with silver nanoparticles. Toxicol. Lett. 2013, 219, 151-159. [CrossRef] [PubMed]

40. Lankoff, A.; Sandberg, W.J.; Wegierek-Ciuk, A.; Lisowska, H.; Refsnes, M.; Sartowska, B.; Schwarze, P.E.; Meczynska-Wielgosz, S.; Wojewodzka, M.; Kruszewski, M. The effect of agglomeration state of silver and titanium dioxide nanoparticles on cellular response of HepG2, A549 and THP-1 cells. Toxicol. Lett. 2012, 208, 197-213. [CrossRef]

41. Grzelak, A.; Wojewódzka, M.; Męczyńska-Wielgosz, S.; Zuberek, M.; Wojciechowska, D.; Kruszewski, M. Crucial role of chelatable iron in silver nanoparticles induced DNA damage and cytotoxicity. Redox Biol. 2018, 15, 435-440. [CrossRef] [PubMed]

42. Breiling, A.; Lyko, F. Epigenetic regulatory functions of DNA modifications: 5-methylcytosine and beyond. Epigenetics Chromatin. 2015, 8, 24. [CrossRef]

43. Gliga, A.R.; Di Bucchianico, S.; Lindvall, J.; Fadeel, B.; Karlsson, H.L. RNA-sequencing reveals long-term effects of silver nanoparticles on human lung cells. Sci. Rep. 2018, 8, 6668. [CrossRef] [PubMed]

44. Xu, Q.H.; Guan, P.; Zhang, T.; Lu, C.; Li, G.; Liu, J.X. Silver nanoparticles impair zebrafish skeletal and cardiac myofibrillogenesis and sarcomere formation. Aquat. Toxicol. 2018, 200, 102-113. [CrossRef]

45. Ambros, V. The functions of animal microRNAs. Nature 2004, 431, 350-355. [CrossRef] [PubMed]

46. Bartel, D.P. MicroRNAs: Target recognition and regulatory functions. Cell 2009, 136, 215-233. [CrossRef]

47. Huang, Y.; Lu, X.; Ma, J. Toxicity of silver nanoparticles to human dermal fibroblasts on microRNA level. J. Biomed. Nanotechnol. 2014, 10, 3304-3317. [CrossRef] [PubMed] 
48. Guennewig, B.; Roos, M.; Dogar, A.M.; Gebert, L.F.; Zagalak, J.A.; Vongrad, V.; Metzner, K.J.; Hall, J. Synthetic pre-microRNAs reveal dual-strand activity of miR-34a on TNF-alpha. RNA 2014, 20, 61-75. [CrossRef] [PubMed]

49. Wan, Y.; Cui, R.; Gu, J.; Zhang, X.; Xiang, X.; Liu, C.; Qu, K.; Lin, T. Identification of Four Oxidative Stress-Responsive MicroRNAs, miR-34a-5p, miR-1915-3p, miR-638, and miR-150-3p, in Hepatocellular Carcinoma. Oxid. Med. Cell. Longev. 2017, 2017, 5189138. [CrossRef] [PubMed]

50. Guo, R.; Wang, Y.; Shi, W.Y.; Liu, B.; Hou, S.Q.; Liu, L. MicroRNA miR-491-5p targeting both TP53 and Bcl-XL induces cell apoptosis in SW1990 pancreatic cancer cells through mitochondria mediated pathway. Molecules 2012, 17, 14733-14747. [CrossRef] [PubMed]

51. Liu, J.; Yan, J.; Zhou, C.; Ma, Q.; Jin, Q.; Yang, Z. miR-1285-3p acts as a potential tumor suppressor miRNA via downregulating JUN expression in hepatocellular carcinoma. Tumour Biol. 2015, 36, 219-225. [CrossRef]

52. Wang, B.Q.; Yang, B.; Yang, H.C.; Wang, J.Y.; Hu, S.; Gao, Y.S.; Bu, X.Y. MicroRNA-499a decelerates glioma cell proliferation while accelerating apoptosis through the suppression of Notch1 and the MAPK signaling pathway. Brain Res. Bull. 2018, 142, 96-106. [CrossRef] [PubMed]

53. Guo, M.; Jiang, Z.; Zhang, X.; Lu, D.; Ha, A.D.; Sun, J.; Du, W.; Wu, Z.; Hu, L.; Khadarian, K.; et al. miR-656 inhibits glioma tumorigenesis through repression of BMPR1A. Carcinogenesis 2014, 35, 1698-1706. [CrossRef] [PubMed]

54. Zhang, L.; Liao, Y.; Tang, L. MicroRNA-34 family: A potential tumor suppressor and therapeutic candidate in cancer. J. Exp. Clin. Cancer Res. 2019, 38, 53. [CrossRef] [PubMed]

55. Shang, A.; Yang, M.; Shen, F.; Wang, J.; Wei, J.; Wang, W.; Lu, W.; Wang, C.; Wang, C. MiR-1-3p Suppresses the Proliferation, Invasion and Migration of Bladder Cancer Cells by Up-Regulating SFRP1 Expression. Cell. Physiol. Biochem. 2017, 41, 1179-1188. [CrossRef]

56. Xu, Z.; Liu, G.; Zhang, M.; Zhang, Z.; Jia, Y.; Peng, L.; Zhu, Y.; Hu, J.; Huang, R.; Sun, X. miR-122-5p Inhibits the Proliferation, Invasion and Growth of Bile Duct Carcinoma Cells by Targeting ALDOA. Cell. Physiol. Biochem. 2018, 48, 2596-2606. [CrossRef] [PubMed]

57. Li, H.; Tian, G.; Tian, F.; Shao, L. Long non-coding RNA TUG1 promotes osteosarcoma cell proliferation and invasion through inhibition of microRNA-212-3p expression. Exp. Ther. Med. 2018, 16, 779-787. [CrossRef]

58. Weng, Y.; Shen, Y.; He, Y.; Pan, X.; Xu, J.; Jiang, Y.; Zhang, Q.; Wang, S.; Kong, F.; Zhao, S.; et al. The miR-15b-5p/PDK4 axis regulates osteosarcoma proliferation through modulation of the Warburg effect. Biochem. Biophys. Res. Commun. 2018, 503, 2749-2757. [CrossRef]

59. Chen, R.; Sheng, L.; Zhang, H.J.; Ji, M.; Qian, W.Q. miR-15b-5p facilitates the tumorigenicity by targeting RECK and predicts tumour recurrence in prostate cancer. J. Cell. Mol. Med. 2018, 22, 1855-1863. [CrossRef] 